\title{
HUBUNGAN DUKUNGAN PSIKOSOSIAL KELUARGA DENGAN TINGKAT STRES PASIEN HIVIAIDS
}

\author{
Pria Wahyu Romadhon Girianto ${ }^{1}$, Wiwik ${ }^{2}$ \\ ${ }^{1}$ Prodi S1 Keperawatan STIKES Karya Husada Kediri \\ ${ }^{2}$ RSUD Kabupaten Kediri \\ Jl. Manila 37 Pesantren Kediri Jawa Timur \\ email : priawahyu88@gmail.com
}

\begin{abstract}
HIVIAIDS was one of psychosocial stressors in a person's life, because the disease was classified as chronic. The aims to determine the correlation between family support and HIVIAIDS patient stress level in Melati Ward Kediri General Hospital. Design was used correlation analytic with cross sectional approach. 20 respondents was taken by accidental sampling technique. Data were analyzed with Spearman rank test $\alpha$ 0.05. The results showed nearly all respondents $80.0 \%$ less to get psychological support from family, and nearly half of the respondents $30.0 \%$ with moderate stress levels. Spearman rank test was obtained $p$ value $=0.024$ that means there is a correlation between family support and HIVIAIDS patient stress level. Correlation coefficient was moderate $(r=-0.503)$ with a negative direction. The level of stress on HIVIAIDS patient depends on their family support. The family as a support system of HIVIAIDS patient should be provide both moriil and material support to prevent high level of stress on HIVIAIDS.
\end{abstract}

Keywords : family support, stress levels, HIVIAIDS

Abstrak : Penyakit HIVIAIDS merupakan salah satu stressor psikososial dalam kehidupan seseorang, karena penyakit ini tergolong kronis. Penelitian ini bertujuan untuk mengetahui hubungan dukungan keluarga dengan tingkat stres pasien HIVIAIDS di Ruang Melati RSUD Kab Kediri. Desain penelitian menggunakan analitik korelasional dengan pendekatan cross Sectional. Didapatkan sampel 20 respondendengan teknik accidental sampling. Data di analisis dengan uji rank spearman dengan $\alpha=0,05$. Hasil penelitian menunjukkan hampir seluruh responden (80\%) kurang mendapatkan dukungan psikososial dari keluarga dan hampir setengah responden 30,0\% dengan tingkat stress sedang. Hasil uji statistik diperoleh $p$ value $=0,024$ artinya ada hubungan dukungan psikososial keluarga dengan tingkat stres pada HIVIAIDS dengan nilai kekuatan hubungan sedang dan arah negative $(r=-0,503)$. Tingkat stress pasien HIV tergantung padakoping masing-masing individu, dan dukungan keluarga hanya dapat sedikit membantu meringankan beban pasien. Keluarga sebagai pendamping terdekat pasien harus selalu siap memberikan bantuan baik moriil maupun materiil.

Kata kunci : dukungan keluarga, tingkat stres, HIVIAIDS

\section{PENDAHULUAN}

AIDS (Acquired Immunodeficiency Syndrome) adalah sekumpulan gejala dan infeksi yang timbul karena rusaknya system kekebalan tubuh akibat infeksi virus HIV(Human Immunodeficiency Virus). Virus tersebut mengakibatkan penurunan dan kerusakan sistem kekebalan tubuh, sehingga orang yang terinfeksi akan menjadi rentan terhadap berbagai macam penyakit (Kusuma, 2011). Penyakit ini menjadi pandemi di seluruh dunia. Hampir semua negara menyumbangkan angka kejadian penyakit HIVIAIDS (Kemenkes, 2013). Menurut data WHO (2014), total kasus infeksi HIV di akhir tahun 2012 mencapai 75 juta orang. Data WHO juga menunjukkan 0,8\% orang dewasa (15-49 tahun) diseluruh dunia hidup dengan HIV.

Data dari UNAIDS (2013) menyebutkan 4,9 juta penduduk Asia Pasifik dinyatakan telah terinfeksi HIV di tahun 2012. Direktorat Jenderal Pengendalian Penyakit dan Penyehatan Lingkungan Kementerian Kesehatan (Ditjen PP\&PL) melaporkan sejak tahun 1987 sampai dengan 2013 penderita yang terinfeksi HIV sebanyak 127.416 penderita, kasus AIDS yang ditemukan sebanyak 52.348 penderita dan jumlah kematian akibat HIVIAIDS sebanyak 9.587 penderita (Kemenkes, 2013). Jumlah penderita HIV di Jawa Timur yang ditemukan sampai 
dengan tahun 2013 sebanyak 6.963 penderita, sedangkan jumlah penderita AIDS sebanyak 1.042 penderita dengan jumlah kematian sebanyak 1.111 orang (Kemenkes,2013). Di Kabupaten Kediri jumlah kunjungan pasien HIV di poli VCT RSUD Kabupaten Kediri sebanyak 659 pasien tercatat mulai Juni 2008 sampai dengan Juni 2016 (Rekam Medis RSUD Pare, 2016).

Tingginya pertumbuhan HIV AIDS di Indonesia dihubungkan oleh 3 hal, yaitu meningkatnya pengguna narkoba suntik, maraknya seks bebas dan kelahiran bayi oleh ibu yang terinfeksi HIV (Kemenkes, 2013). Penyakit HIVIAIDS menimbulkan masalah yang cukup luas, baik pada orang yang terinfeksi HIVIAIDS (ODHA) maupun orang yang hidup dengan penderita HIV / AIDS (OHIDA). Masalah yang muncul adalah masalah fisik, sosial dan emosional. Masalah emosional berkaitan dengan gangguan psikologis seperti cemas, stres, depresi maupun gangguan emosional lainnya.

Di Indonesia, 60\% ODHA yang ditemukan mengalami depresi (Spiritia, 2013). Kondisi fisik yang memburuk, ancaman kematian, serta tekanan sosial yang begitu hebat menyebabkan ODHA cenderung mengalami masalah emosional yaitu depresi (Darwin, 2014). Di Indonesia dari hasil penelitian kualitatif yang dilakukan oleh Iskandar (Darwin, 2014) pada 6 orang pasien HIV / AIDS di Jakarta didapatkan keseluruhan informan mengalami depresi. Hasil studi ini juga didukung oleh penemuan Carter (Vitriawan, 2007), sebagian besar pasien HIV / AIDS Sekitar 72\% mengatakan mereka mengalami depresi, 65\% mengalami kegelisahan, dan 48\% insomnia.

Untuk penderita HIVIAIDS di Ruang Melati dalam 3 bulan ini semakin meningkat dari bulan Juni 8 penderita, Juli 9 penderita dan Agustus 12 penderita. Hasil studi pendahuluan terhadap 5 orang didapatkan 3 pasien mengalami stres sedang (60\%) dan ada 2 pasien (40\%) yang mengalami stres berat (Studi Pendahuluan, 20 Agustus 2016). Melihat tingginya prevalensi stres di atas maka masalah HIVIAIDS saat ini bukan hanya penyakit menular semata, tetapi sudah menjadi masalah kesehatan masyarakat yang sangat luas. Ketika individu dinyatakan terinfeksi HIV, sebagian besar menunjukkan perubahan karakteristik psikososial yaitu hidup dalam stres, depresi, merasa kurang dukungan dan perubahan perilaku. Stres pada penderita HIVIAIDS akan semakin memperburuk kondisinya. Dampak psikososial pada pasien HIVIAIDS pada awalnya belum muncul gejala, stres masih ringan. Tetapi seiring dengan berjalannya waktu dimana fungsi imun semakin turun dan mulai ada tanda yang berhubungan dengan HIV seperti ruam kulit, penurunan berat badan, sesak nafas, dan sebagainya maka pasien akan semakin meningkat stresnya, semakin cemas dan depresi. Mungkin pula disertai dengan gagasan bunuh diri, gangguan tidur dan sebagainya (Muhammad Baitul Alim, 2010). Oleh karena itu, penanganan tidak hanya dari segi medis tetapi melibatkan aspek psikososial agar ODHA (Orang dengan HIVIAIDS) mampu beradaptasi akibat kesedihan, kegelisahan dan depresi yang dialaminya (Djoerban dalam Darwin, 2014).

Dukungan psikososial adalah suatu keadaan yang bermanfaat bagi individu yang diperoleh dari orang lain yang dapat dipercaya, sehingga seseorang akan tahu bahwa ada orang lain yang memperhatikannya, melayani dan mencintai (Darwin, 2014). Dukungan psikososial yang diberikan dapat berupa informasi atau nasihat verbal atau non verbal, bantuan nyata, atau tindakan yang diberikan oleh keakraban sosial. Selain itu, dukungan sosial bisa didapat karena kehadiran mereka mempunyai manfaat secara emosional serta memberikan efek perilaku bagi pihak penerima. Sumber dukungan psikososial dapat diperoleh dari keluarga, pasangan hidup, teman atau sahabat, tenaga kesehatan maupun jaringan sosial. Dukungan psikososial pada ODHA dapat mempengaruhi kondisi fisik, mental, sosial dan perilaku sehat serta kualitas hidup. Dampak lain dukungan sosial adalah dapat mempengaruhi kepatuhan ODHA dalam menjalani pengobatan ARV, mampu membantu seseorang mengurangi masalah kesehatan yang lebih serius. Dampak lain dukungan psikososial adalah dapat me- 
nurunkan stres dan angka kematian, terutama pada penyakit kardiovaskular, neuroendokrin dan penyakit auto immune (Kusuma, 2011). Peran perawat dalam hal ini adalah memberikan asuhan keperawatan secara komprehensif, baik pemenuhan kebutuhan fisik maupun psikososial atau mental pasien.

Berdasarkan permasalahan di atas maka peneliti tertarik untuk melakukann penelitian tentang "Hubungan Dukungan Keluarga terhadap Tingkat Stres pada Pasien HIVIAIDS di Ruang Melati RSUD Kabupaten Kediri".

\section{METODE PENELITIAN}

Desain penelitian korelasional analitik. Pendekatan yang digunakan adalah cross sectional. Sampel dalam penelitian ini adalah pasien yang sedang menjalani rawat inap di ruang Melati RSUD Kabupaten Kediri sebanyak 20 pasien, dengan teknik Accidental Sampling. Kriteria inkluasi dalam penelitian ini adalah pasien dengan diagnose HIVIAIDS positif, pasien HIV IAIDS di Ruang Melati RSUD Kabupaten Kediri yang bisa membaca dan menulis, pasien HIVIAIDS yang bersedia menanda- tangani informed consent, pasien yang di tunggu oleh keluarga yang tinggal satu rumah, dan pasien yang berumur 20 - 55 tahun. Dengan Kriteria ekslusi pasien HIVIAIDS di yang sudah mengalami depresi dan yang secara medis tidak bisa dijadikan responden dalam penelitian (seperti : SOL, Meningitis, Delirium, Malnutrisi berat). Teknik pengumpulan data dengan instrument berupa kuesioner untuk mengukur dukungan psikososial keluarga dan tingkat stress.

\section{HASIL PENELITIAN}

Data hasil penelitian didapatkan hampir seluruh responden (80\%) yakni 16 responden kurang mendapatkan dukungan dari keluarga, 10\% dukungan cukup dan kurang

Berdasarkan data Tingkat Stress Pasien HIV di Ruang Melati RSUD Kabupaten Kediri, hampir setengah responden (30\%) yakni 6 responden dengan tingkat stress sedang. 25\% stress ringan dan stress berat, $15 \%$ stress sangat berat dan hanya $5 \%$ yang tidak ada gejala.

Tabel 1 Tabulasi Silang Dukungan Keluarga dengan Tingkat Stress Pasien HIV di Ruang Melati RSUD Kabupaten Kediri

\begin{tabular}{|c|c|c|c|c|c|c|c|c|c|c|c|c|}
\hline \multirow{3}{*}{$\begin{array}{l}\text { Dukungan } \\
\text { Kelurga }\end{array}$} & \multicolumn{12}{|c|}{ Tingkat Stress Pasien HIV } \\
\hline & \multicolumn{2}{|c|}{$\begin{array}{c}\text { Tidak ada } \\
\text { gejala }\end{array}$} & \multicolumn{2}{|c|}{$\begin{array}{l}\text { Stres } \\
\text { ringan }\end{array}$} & \multicolumn{2}{|c|}{$\begin{array}{l}\text { Stres } \\
\text { Sedang }\end{array}$} & \multicolumn{2}{|c|}{$\begin{array}{l}\text { Stres } \\
\text { Berat }\end{array}$} & \multicolumn{2}{|c|}{$\begin{array}{c}\text { Stres Sangat } \\
\text { Berat }\end{array}$} & \multicolumn{2}{|c|}{ Total } \\
\hline & $\mathrm{F}$ & $\%$ & $\mathrm{~F}$ & $\%$ & $\mathrm{~F}$ & $\%$ & $\mathrm{~F}$ & $\%$ & $\mathrm{~F}$ & $\%$ & $\mathrm{~F}$ & $\%$ \\
\hline Kurang & $\mathrm{O}$ & $0, \mathrm{O}$ & 3 & 18,8 & 5 & 31,2 & 5 & 31,2 & 3 & 18,8 & 16 & 100 \\
\hline Cukup & 1 & 50,0 & 1 & 50,0 & $\mathrm{O}$ & $\mathrm{O}, \mathrm{O}$ & $\mathrm{O}$ & $\mathrm{O}, \mathrm{O}$ & $\mathrm{O}$ & $\mathrm{O}, \mathrm{O}$ & 2 & 100 \\
\hline Baik & $\mathrm{O}$ & $\mathrm{O}, \mathrm{O}$ & 1 & 50,0 & 1 & 50,0 & $\mathrm{O}$ & $\mathrm{O}, \mathrm{O}$ & $\mathrm{O}$ & $\mathrm{O}, \mathrm{O}$ & 2 & 100 \\
\hline Total & $\mathbf{1}$ & 5,0 & 5 & 25,0 & 6 & 30,0 & 5 & 25,0 & 3 & 15,0 & 20 & 100 \\
\hline$\alpha=0,05$ & $\rho=0,024$ & Jilai & eff & ient C & 97 & latio & & 0,503 & & & & \\
\hline
\end{tabular}

Berdasarkan tabel tersebut diketahui bahwa responden yang mendapatkan dukungan kurang hampir setengah responden $(31,2 \%)$ mengalami tingkat stress sedang dan berat, yang mendapatkan dukungan keluarga cukup setengahnya $(50 \%)$ mengalami tingkat stress ringan dan tidak ada gejala, sedangkan pada responden yang mendapatkan dukungan baik setengahnya (50\%) mengalami stress ringan dan sedang.
Hasil analisis data menggunakan Uji Spearman Rank didapatkan $p$-value $=$ 0,024 dengan $\alpha=0,05$, sehingga $\mathrm{H}_{0}$ ditolak, sehingga dapat disimpulkan ada hubungan dukungan psikosisal keluarga dengan tingkat stress pasien HIV. Nilai coefficient correlation $(r)$ sebesar $-0,503$ artinya kekuatan hubungan termasuk kategori sedang. coefficient correlation $(r)$ negatif artinya semakin baik dukungan keluargamaka semakin rendah tingkat stress pasien HIV, begitu juga sebaliknya 
jika kurang dukungan psikososial keluarga maka semakin tinggi tingkat stress pasien.

\section{PEMBAHASAN}

\section{Identifikasi Dukungan Keluarga Kepada Pasien HIV di Ruang Melati RSUD Kabupaten Kediri}

Berdasarkan hasil penelitian menunjukkan bahwa hampir seluruh responden $80,0 \%$ kurang mendapatkan dukungan dari keluarga. Menghadapi berbagai masalah terkait penyakit HIV I AIDS, dalam hal ini responden sangat membutuhkan dukungan dari keluarga yang akan meningkatkan harapan dan kualitas hidupnya. Hal ini sesuai dengan yang diungkapkan Laserman \& Perkins (2001) dalam Kusuma (2011), dukungan keluarga sangat dibutuhkan oleh orang dengan HIV I AIDS sebagai sistem pendukung utama sehingga dapat mengembangkan respon koping yang efektif untuk beradaptasi dengan baik dalam menangani stresor yang dihadapi terkait penyakitnya baik fisik, psikologis maupun sosial. Perawatan di rumah merupakan kesinambungan dari perawatan di rumah sakit. Perawatan di rumah adalah perawatan yang diberikan kepada pasien di tempat tinggalnya sendiri, mencakup perawatan fisik dasar, dukungan psikososial, dan aktivitas spiritual. Perawatan ini bisa dilakukan oleh pasien sendiri atau keluarga.

Pada penelitian ini didapatkan bahwa responden merasa orang yang paling dekat dan berharga bagi kehidupannya adalah keluarga termasuk orang tua, pasangan serta anggota keluarga lainnya. Keluarga merupakan tempat untuk saling bergantung dan memiliki pengaruh paling besar terhadap pasien. Berdasarkan hasil penelitian diketahui bahwa hampir seluruh responden $80,0 \%$ dengan kriteria dukungan kurang terutama dukungan sosial dan emosional. Hal tersebut disebabkan karena terdapat keluarga yang berespon tidak terima atau menolak terhadap kenyataan bahwa anggota keluarganya didiagnosis HIV / AIDS. Respon Menolaknya keluarga dapat berupa sikap menyangkal (tidak percaya, kaget / shock, marah) serta depresi (kekecewaan, khawatir dan sedih). Keluarga biasanya hanya mengetahui bahwa selama ini kondisi anggota keluarganya baik-baik saja dan tidak melakukan perbuatan yang memiliki resiko terinfeksi HIVIAIDS. Keluarga merasa kecewa dengan yang terjadi pada anggota keluarganya. Keluarga sangat menyayangkan sekali terhadap perilaku buruk yang telah dilakukan anggota keluarganya dan hanya bisa menangis menyesali perbuatan anggota keluarganya sehingga berakibat menderita penyakit HIVIAIDS. Keluarga khawatir jika penyakit HIVIAIDS dapat menular pada anggota keluarga lainnya seperti perlakuan keluarga yang menyarankan pasien untuk dibedakan dalam penggunaan sabun, alat makan dan lain sebagainya.

\section{Identifikasi Tingkat Stres Pasien HIV di Ruang Melati RSUD Kabupaten Kediri}

Berdasarkan hasil penelitian menunjukkan bahwa hampir setengah responden $(30,0 \%)$ dengan tingkat stress sedang. Saat seseorang terdiagnosis HIV, cenderung mengalami masalah psikologis yang ditandai dengan menolak, marah, syok, depresi. Saat-saat seperti itu merupakan gejala psikologis yang justru dapat membuat orang tersebut semakin stres dalam menjalani hidup (Depkes RI, 2014). Menurut Stuart \& Sundeen (2011), tanda dan gejala yang muncul pada orang dengan gangguan hubungan sosial : menarik diri, terlihat dari tingkah laku klien yaitu : kurang spontan, apatis, ekpresi wajah kurang berseri, afek tumpul, tidak merawat dan memperhatikan kebersihan diri, komunikasi verbal menurun atau tidak ada, mengisolasi diri, tidak atau kurang sadar dengan lingkungan sekitarnya, pemasukan makanan dan minuman terganggu, kurang energi, aktivitas menurun, harga diri rendah, membentuk posisi janin saat tidur, menolak berhubungan dengan orang lain, gairah seksual menurun, dan ragu terhadap keyakinan yang dianut.

Berdasarkan fakta di tempat penelitian bahwasanya masih ada pasien HIVIAIDS yang memiliki tingkat stress yang tinggi. Hal ini dikarenakan mereka merasa diasingkan oleh masyarakat sekitar. 
Masyarakat menganggap bahwa seseorang yang terjangkit HIVIAIDS adalah orang yang suka berperilaku tidak baik dan menyalahi aturan baik adat maupun agama. Hal tersebut menyebabkan berbagai permasalahan yang dihadapi ODHA (Orang Dengan HIV / AIDS) seperti menarik diri, gangguan sosialisasi, gangguan peran, kekhawatiran terhadap hubungan dengan pasangan, perubahan gaya hidup, kehilangan semangat akibat adanya pembatasan-pambatasan serta adanya perasaan terisolasi. Temuan dalam penelitian ini bahwa pasien baru terdiagnosa HIV mayoritas berpendidikan dasar, umur pasien masih tergolong produktif serta pekerjaan swasta (sopir, sales dan pekerja pabrik). Pendidikan SD dan SMP termasuk dalam tingkat pendidikan dasar sehingga berdampak pada kurangnya informasi mengenai beberapa faktor yang dapat menyebabkan terjangkit penyakit HIV. Sedangkan untuk pekerjaan menunjukkan bahwa responden tidak memiliki batas waktu yang ditentukan serta pekerjaan yang jauh dari keluarga terutama istri mengakibatkan terjerumusnya ke pergaulan bebas. Respon menolak dari responden saat didiagnosis HIVIAIDS dapat berupa menyangkal (tidak percaya, kaget/Shock, tidak adil, dan marah), tawar menawar (pengandaian), maupun depresi (menarik diri, khawatir akan masa depan dan perasaan sedih terhadap keadaan yang dialami). Hal tersebut terjadi karena pasien merasa belum siap dan merasa tidak mungkin menderita penyakit HIV / AIDS serta tidak percaya hal ini bisa terjadi pada dirinya.

\section{Analisis Hubungan Dukungan Keluarga dengan Tingkat Stres Pasien HIV di Ruang Melati RSUD Kabupaten Kediri}

Berdasarkan hasil penelitian diketahui bahwa dari responden yang mendapatkan dukungan kurang hampir setengah responden $(31,2 \%)$ mengalami tingkat stress sedang dan berat, yang mendapatkan dukungan keluarga cukup setengahnya (50\%) mengalami tingkat stress ringan dan tidak ada gejala, sedangkan pada responden yang mendapatkan dukungan baik setengahnya (50\%) mengalami stress ringan dan sedang.
Berdasarkan analisis data menggunakan Uji Spearman Rank didapatkan $p$-value $=0,024$ dan $\alpha=0,05$ sehingga $\mathrm{H}_{0}$ ditolak, artinya ada hubungan dukungan keluarga dengan tingkat stress pasien HIV. Nilai Coefficient Correlation (r) sebesar -0,503 artinya kekuatan hubungan termasuk kategori sedang. Hasil coefficient correlation ( $r$ ) adalah negatif artinya semakin baik dukungan keluarga maka semakin rendah tingkat stress pasien HIV, begitu juga sebaliknya jika kurang dukungan keluarga maka semakin tinggi tingkat stressnya. Dalam menghadapi berbagai masalah terkait penyakit HIVIAIDS, pasien sangat membutuhkan dukungan dari keluarga yang akan meningkatkan harapan dan kualitas hidupnya. Hal ini sesuai dengan pernyataan Laserman \& Perkins (2001) dalam Kusuma (2011), dukungan keluarga sangat dibutuhkan oleh orang dengan HIV / AIDS sebagai sistem pendukung utama sehingga dapat mengembangkan respon koping yang efektif untuk beradaptasi dengan baik dalam menangani stresor yang dihadapi terkait penyakitnya baik fisik, psikologis maupun sosial. Tanggapan positif dari keluarga dan masyarakat terhadap apa yang dilakukan ODHA akan memberikan perasaan bahwa dirinya berguna atau bermanfaat bagi orang lain. Perasaan tersebut akan menuntunnya pada kesadaran bahwa kehidupannya masih bermakna, meskipun dirinya mengidap HIVIAIDS (Astuti dan Budiyani, 2010). Jika ODHA merasa lebih berguna maka permasalahan psikologis juga dapat dikurangi.

Adanya dukungan sosial dari keluarga akan memberi pengalaman pada individu bahwa dirinya dicintai, dihargai, dan diperhatikan. Perhatian dan dukungan dari orang lain akan menumbuhkan harapan untuk hidup lebih lama, sekaligus dapat mengurangi kecemasan individu. Sebaliknya, kurang atau tidak, tersedianya dukungan sosial akan menjadikan individu merasa tidak berharga dan terisolasi. Dukungan sosial sangat diperlukan oleh ODHA agar manajemen psikososial pasien menjadi baik. Dalam penelitian ini, adapun bentuk dukungan keluarga yang dibutuhkan pasien meliputi : dukungan psikososial, dukungan instrumental dan 
dukungan informasional. Dukungan psikososial merupakan dukungan yang paling dibutuhkan responden dalam menghadapi penyakit HIVIAIDS yang diderita. Adapun bentuk dukungan psikososial yang dibutuhkan pasien berupa perhatian, semangat/ support, kasih sayang, kedamaian. Responden membutuhkan perhatian terhadap konsumsi ARV serta kondisi kesehatannya, sehingga dorongan keluarga akan sangat membantu peningkatan harapan dan kualitas hidupnya. Dukungan berupa perhatian dari keluarga diharapkandapat menunjukkan bahwa keluarga masih peduli dan menganggap pasien merupakan bagian dari keluarga, serta mencintainya walaupun saat ini menderita penyakit HIVIAIDS.

Tingkat hubungan yang sedang dalam penelitian ini dikarenakan tingkat stress yang dialami pasien HIV sangat berkaitan erat dengan aspek pasien sendiri. Individu melibatkan usaha - usaha untuk mengatur emosinya untuk menyesuaikan diri dengan dampak yang ditimbulkan oleh situasi tersebut. Responden merasa perasaan bersalah dengan melakukan pengandaian pada dirinya sendiri, jika saja dulunya tidak

\section{DAFTAR PUSTAKA}

Alimul, A. 2007. Riset Keperawatan dan Teknik Penulisan IImiah. Jakarta : Salemba Medika.

Arikunto. 2009. Prosedur Penelitian Suatu Pendekatan Praktek. Jakarta:Rineka Cipta

Ditjen PP\&PLKemenkes RI.2013. Hubungan antara Tingkat Harga Diri dengan Kecemasan Interaksi Sosial pada Remaja denganHuman Immunodeficiency Virus/Acquired Immune Deficiency Syndrome(HIVIAIDS). http://sheringtipshidupsehat.co.id

Hidayati, Ema. 2011. StrategiCopingStressPerempuan dengan HIV/AIDS. Semarang : FakultasDakwah

IAINWalisongoSemarangdan Lakpesdam LDNU KotaSemarang lqrame. 2010. Tingkat Pengetahuan, Sikap dan Penerimaan Keluarga Penderita HIVIAIDS terhadap melakukan perbuatan yang memiliki resiko tersebut maka tidak akan menderita HIVIAIDS. Sehingga dapat disimpulkan bahwa tinggi rendahnya tingkat stress pasien HIV semuanya kembali ke diri mereka sendiri, dukungan keluarga hanya dapat sedikit membantu meringankan beban pasien. Pasien HIV harus berusaha sendiri untuk menyesuaikan diri terhadap keluarga maupun lingkungan sekitar.

\section{KESIMPULAN DAN SARAN}

Ada hubungan dukungan psikososial keluarga dengan tingkat stres pasien HIV, dengan kekuatan sedang dan arah hubungan negatif. Artinya semakin baik dukungan keluarga maka semakin rendah tingkat stress pasien HIV.

Diharapkan bagi penyedian layanan kesehatan, memberikan konseling dan melakukan home care pasien HIV. Keluarga diharapkan lebih aktif dalam memberikan dukungan terhadap ODHA terutama dalam aspek dukungan psikososial dan dukungan penghargaan berupa perhatian, empati, berbagi perasaan dan menghargai ODHA.

Penderita HIVIAIDS di Rumah Sakit Haji Adam Malik, Medan. Medan : Fakultas Kedokteran Universitas Sumatera Utara Medan

Khasanah. 2015. Tinjauan Pustaka tentang Penerimaan. http://digilib.uinsby.ac.id

Kusuma, Heni. 2015. Hubungan antara Tingkat Harga Diri dengan Kecemasan Interaksi Sosial pada Remaja yang Telah Dinyatakan Positif Menderita Human Immuno deficiency Virus / Acquired Immune Deficiency Syndrome (HIVIAIDS). Jakarta : Program Pasca Sarjana Fakultas IImu Keperawatan Universitas Indonesia

Martha, Davis. 2015. Panduan Relaksasi dan Reduksi Stres. Edisi III. Jakarta : EGC

Masruroh. 2014. Jurnal Edu Health. Volume 4. Nomor 1, April 2014. Jombang: Fakultas Ilmu Kesehatan 
Universitas Pesantren Tinggi Darul Ulum Jombang

Naricu. 2011. Psikologi Pasien HIVIAIDS dan Kanker. http://ch2ymanizzz..co.id

Notoatmodjo, S. 2010. Metodologi Penelitian Kesehatan. Jakarta : Rineka Cipta.

Nurbani. 2009. Dukungan Sosial PadaODHA. Universitas Gunadarma

Nursalam. 2008. Konsep \& Penerapan Metodologi Penelitian IImu Keperawatan (Pedoman Skripsi, Tesis dan Instrumen Penelitian Keperawatan). Surabaya : Salemba Medika

Paramita. 2014. Pengaruh Penerimaan Diri terhadap Penyesuaian Diri Penderita Lupus. Surabaya : Universitas Airlangga

Purwanto. 2008. Metode Penelitian Kuantitatif untuk Psikologi dan Pendidikan. Yogyakarta : Pustaka Pelajar

Putri, Rima Novia. 2011. Hubungan Tingkat Stres Klien DM Tipe 2 dengan Kadar Glukosa Darah di Poliklini Kkhusus Penyakit Dalam RSUP Dr.M. Djamil Padang Tahun 2009. Fakultas Keperawatan Universitas Andalas

Retno. 2016. Faktor yang Mempengaruhi Stres. http://dianhusadaretnoo.co.id

Riduwan. 2009. Belajar Mudah Penelitian untuk Guru - Karyawan dan Peneliti Pemula. Bandung : Alfa Beta
Riduwan. 2012. Dasar-Dasar Statistika. Bandung : Alfa Beta

Setiadi, 2007. Konsep dan Penulisan Riset Keperawatan. Yogyakarta : Graha IImu.

Sugiyono. 2008. Metode Penelitian Administrasi. Bandung : Alfabeta

Sugiyono. 2011. Metode Penelitian Kuantitatif Kualitatif dan R\&D. Bandung : Alfabeta

Ulumuddin. 2011. Hubungan Tingkat Stres Dengan Kejadian Insomnia Pada Mahasiswa Program Studi IImu Keperawatan Universitas Diponegoro. Semarang : Program Studi Keperawatan Fakultas Kedokteran Universitas Diponegoro

Utami. 2013. Hubungan Antara Dukungan Sosial Keluarga dengan Penerimaan Diri Individu yang Mengalami Asma. Bali : Program Studi Psikologi, Fakultas Kedokteran, Universitas Udayana sintya_noviana@yahoo.com

Vitriawan. 2007. Pengalaman Pasien Pertama Kali Terdiagnosis HIVIAIDS: Studi Fenomenologi dalam Perspektif Keperawatan. Jurnal Keperawatan Indonesia, Volume 11, No.1, Maret 2007; hal 6-12

Widiada, Deny. 2016. Kuesioner depression Anxiety Stress Scales DASS 42. www.academia.edu. 